\title{
ANALISIS FAKTOR-FAKTOR YANG MEMPENGARUHI PENDAPATAN PETANI GAMBIR DI DESA BANDAR BARU KECAMATAN SITELLU TALI URANG JEHE KABUPATEN PAKPAK BHARAT
}

\author{
Salman Syarief 1)*, Nurlina Basyah ${ }^{1)}$, Mawar Candra Berutu ${ }^{1)}$ \\ 1) Fakultas Ekonomi, Universitas Samudra \\ Penulis korespondensi: salman@unsam.ac.id*, nurlina@unsam.ac.id, candraberutu5@gmail.com
}

\begin{abstract}
Abstrak
Pendapatan petani gambir adalah pendapatan yang diperoleh dari kegiatan pengolahan tanaman gambir menjadi bahan baku yang dijual dengan harga yang berlaku pada pasar. Penelitian ini bertujuan untuk mengetahui luas lahan, produksi, harga, jam kerja, dan biaya produksi terhadap pendapatan petani gambir di desa Bandar Baru Kecamatan Sitellu Tali Urang Jehe Kabupaten Pakpak Bharat. Metode analisis menggunakan regresi linier bergand. Hasil penelitian menunjukkan bahwa variabel luas lahan tidak berpengaruh positif dan signifikan terhadap pendapatan petani gambir di Desa Bandar Baru dengan nilai t-hitung sig, 0,723 >0,005. Sedangan variabel produksi dengan nilai t-hitung sig, $0,000<0,005$, variabel harga dengan nilai t-hitung sig, $0,003<0,005$, variabel jam kerja dengan nilai t-hitung sig, $0,000<0,005$, dan variabel biaya produksi dengan nilai t-hitung sig, $0,000<0,005$. Artinya bahwa variabel produksi, harga, jam kerja, dan biaya produksi berpengaruh positif dan signifikan terhadap pendapatan petani gambir di Desa Bandar Baru Kecamatan Sitellu Tali Urang Jehe Kabupaten Pakpak Bharat.
\end{abstract}

Keywords: Luas Lahan, Produksi, Harga, Jam Kerja, Biaya, Pendapatan

\section{Article Information:}

Received Date: 5 September 2021

Revised Date: 18 September 2021

Accepted Date: 6 Oktober 2021 


\section{PENDAHULUAN}

Pertanian melalui sektor pertanian khususnya di daerah yang memiliki potensi unggulan yang diharapkan dapat meningkatkan pendapatan daerah terutama dari penduduk pedesaan yang masih berada pada garis kemiskinan. Untuk itu, berbagai investasi dan kebijakan telah dilakukan pemerintah untuk mendorong pertumbuhan disektor pertanian. Sektor pertanian menjadi prioritas yang dapat diandalkan dalam pemulihan perekonomian baik ditingkat regional maupun ditingkat nasional. Berbagai strategi telah diterapkan dalam pengembangan sektor pertanian untuk meningkatkan kesejahteraan perekonomian petani beserta keluargannya yang juga berhubungan dengan pengembangan pertanian.

Sektor pertanian menjadi prioritas pada negara-negara berkembang seperti Indonesia karena sektor ini ditinjau dari berbagai segi merupakan sektor yang dominan dalam ekonomi nasional. Kontribusi terhadap pendapatan nasional, peranannya dalam penyerapan tenaga kerja pada penduduk bertambah dengan cepat, serta berkontribusi dalam menghasilkan devisa negara. Salah satu subsektor pertanian ialah dibidang perkebunan.

Negara agraris seperti Indonesia sebagian besar penduduk hidup dari hasil pertanian, seperti perkebunan, perikanan, dan tanaman hultikutura. Sektor pertanian berperan penting dalam kegiatan perekonomian penduduk Indonesia. Besarnya pengaruh sektor pertanian terhadap perekonomian, cenderung berpengaruh positif juga terhadap peningkatan pendapatan nasional yang diperoleh dari sektor pertanian.
Pembangunan pertanian perlu diperhatikan dalam rangka mewujudkan kesejahteraan bagi penduduk yang bekerja dalam sektor pertanian. Perwujudan ini melalui sistem pengelolaan pertanian dengan penerapan teknologi dalam pengelolaan serta Pendayagunaan sumber daya pertanian menjadi kunci dalam meningkatkan produktivitas petani sehingga sumber daya yang terbatas itu dapat dialokasikan seefisien mungkin. Pengelolaan yang tidak bijaksana dapat berakibat menurunnya kualitas sumber daya, mempengaruhi produksi pertanian hingga pada akhirnya pendapatan yang diperoleh petani cenderung menurun.

Pertanian di Indonesia tersebar hampir diseluruh provinsi-provinsi di Indonesia, salah satunya adalah Provinsi Sumatera Utara dengan subsektor perkebunanan dan hultikultura yang besar terhadap penyediaan konsumsi pangan masyarakat dan penyediaan bahan baku untuk industri pengolahan. Dibidang penyedian bahan konsumsi pangan, subsektor hultikultura seperti jagung, sayur-sayuran, kedelai, ubi kayu, ubi jalar, kacang-kacangan, dan sebagainya menjadi fokus pertanian.

Kabupaten Pakpak Bharat adalah Sala satu kabupaten dalam Sumatera Utara dengan sub sektor perkebunan yang bermacam-macam seperti; gambir, karet, kopi, kemenyan, kayu manis dan lain sebagainnya. Gambir merupakan komoditas perkebunan yang paling luas diantara perkebunan lainnya serta banyak masyarakat yang menggantungkan hidupnya melalui perkebunan ini. Gambir memiliki latin Unicaria gambir adalah tanaman yang tumbuh subur pada 
daerah ketinggian antara 200-800 meter diatas permukaan air laut.

Pendapatan petani gambir ialah pendapatan yang diperoleh dari usaha bertani gambir dengan tujuan untuk memenuhi kebutuhan rumah tangganya tercapai. Pendapatan petani gambir erat kaitannya dengan luas lahan yang dikelola oleh petani.

Tabel 1. Luas dan Produksi Gambir Kabupaten Pakpak Bharat

\begin{tabular}{ccccc}
\hline Tahun & $\begin{array}{c}\text { Luas } \\
\text { lahan } \\
\text { (Ha) }\end{array}$ & $\begin{array}{c}\text { Perkemba } \\
\text { ngan } \\
\text { luas lahan }\end{array}$ & $\begin{array}{c}\text { Produksi } \\
\text { (ton) }\end{array}$ & $\begin{array}{c}\text { Perkemba } \\
\text { ngan } \\
\text { produksi }\end{array}$ \\
\hline 2014 & $1.657,00$ & - & $1.880,50$ & - \\
\hline 2015 & $1.332,00$ & $-24,40$ & $1.004,00$ & $-87,30$ \\
\hline 2016 & $1.560,48$ & 14,64 & $1.559,94$ & 35,64 \\
\hline 2017 & $1.374,86$ & $-13,50$ & $1.573,75$ & 0,88 \\
\hline 2018 & $1.700,96$ & 19,17 & $2.732,47$ & 42,40 \\
\hline 2019 & $1.577,00$ & $-7,86$ & $1.957,00$ & $-39,62$ \\
\hline \multicolumn{5}{l}{ Sumber : BPS Pakpak Bharat 2020}
\end{tabular}

Merujuk pada tabel 1. Perkembangan Luas Lahan perkebunan gambir di Kabupaten Pakpak Bharat mengalami peningkatan dan penurunan setiap tahunnya. Peningkatan perluasan lahan perkebunan gambir masyarakat dilihat dari nilai perkembangannya pada tahun 2018 tercatat 19,17\% disusul pada tahun 2016 tercatat 14,64\%. Penurunan luas lahan perkebunan gambir masyarakat tertinggi berdasarkan nilai perkembangannya pada tahun 2015 tercatat $24,40 \%$ disusul pada tahun 2017 tercatat 13,50\% kemudian pada tahun 2019 tercatat $7,86 \%$. Peningkatan dan penurunan luas lahan perkebunan gambir masyarakat tersebut menimbulkan masalah pada produksi gambir Kabupaten Pakpak Bharat.

Produksi merupakan faktor pendukung untuk peningkatan pendapatan masyarakat. Peningkatan produksi perkebunan gabir masyarakat tertinggi berdasarkan nilai perkembangannya tercatat pada tahun 2018 sebesar 42,40\% disusul pada tahun 2016 sebesar $35,64 \%$ kemudian peningkatan produksi terendah berdasarkan nilai perkembangannya tercatat pada tahun 2017 sebesar $0,88 \%$. Penurunan produksi hasil perkebunan masyarakat tertinggi berdasarkan nilai perkembangannya tercatat pada tahun 2015 sebesar $-87,30 \%$ dan kemudian pada tahun 2019 tercatat sebesar $-39,62 \%$.

Tabel 2. Luas Lahan dan Produksi Komoditas Gambir Kecamatan Sitellu Tali

\begin{tabular}{ccccc}
\hline & $\begin{array}{c}\text { Luas } \\
\text { lahan } \\
\text { Tha) }\end{array}$ & $\begin{array}{c}\text { Perkemba } \\
\text { ngan } \\
\text { luas lahan }\end{array}$ & $\begin{array}{c}\text { Produksi } \\
\text { (ton) }\end{array}$ & $\begin{array}{c}\text { Perkemba } \\
\text { ngan } \\
\text { produksi }\end{array}$ \\
\hline 2014 & 976,00 & - & $1.157,00$ & - \\
\hline 2015 & 643,00 & $-51,79$ & 238,00 & $-386,13$ \\
\hline 2016 & 967,00 & 33,50 & 822,65 & 71,07 \\
\hline 2017 & 889,00 & $-8,77$ & $1.034,00$ & 20,44 \\
\hline 2018 & $1.082,00$ & 17,84 & $1.834,11$ & 43,62 \\
\hline 2019 & $1.082,00$ & 0 & $1.834,00$ & $-0,006$ \\
\hline \multicolumn{5}{c}{ Sumber: BPS Pakpak Bharat 2020 }
\end{tabular}

Berdasarkan tabel 1.2 luas lahan perkebunan gambir masyarakat di Kecamatan Sitellu Tali Urang Jehe sebagai salah satu Kecamatan penghasil terbesar komoditas gambir di Kabupaten Pakpak Bharat dilihat perkembangannya tertinggi tercatat pada tahun 2016 sebesar 33,50\% kemudian pada tahun 2018 sebesar $17,84 \%$. Nilai penurunan pada Luas Lahan dilihat dari nilai perkembangannnya tertinggi terjadi pada tahun 2015 sebesar $51,79 \%$ kemudian pada tahun 2017 sebesar 8,77\%. Sedangkan pada tahun 2019 sama sekali tidak terjadi perubahan luas lahan perkebunan petani gambir.

Berdasarkan nilai perkembangan Produksi komoditas gambir masyarakat di Kecamatan Sitellu Tali Urang Jehe, juga terjadi peningkatan 
dan penurunan nilai perkembangannya. Peningkatan produksi komoditas gambir di kecamatan tersebut berdasarkan nilai perkembangannya tertinggi terjadi pada tahun 2016 sebesar 71,07\%, 2018 sebesar 43,62\%, 2017 sebesar 20,44\%. Nilai penurunan produksi komoditas gambir tertinggi berdasarkan nilai perkembangan tercatat pada tahun 2015 sebesar 386,11\% kemudian pada tahun 2019 sebesar $0,006 \%$. Terjadinya peningkatan dan penurunan baik luas lahan maupun produksi gambir di Kabupaten Pakpak Bharat disebabkan oleh pengalihan lahan pertanian gambir kegiatan pertanian lain. kegiatan pertanian lain dapat berupa; tanaman padi, tanaman jagung, tanaman cabai, sayuran dan lain sebagainya.

Alih fungsi lahan perkebunan gambir kedalam sektor lain menyebabkan penurunan produksi gambir. Peningkatan produksi juga dipengaruhi oleh kondisi cuaca dan pertumbuhan tanaman gambir. Proses pemanenan daun gambir perlu diperhatikan sehingga tidak menghambat proses munculnya cabang baru pada tanaman gambir. Selain itu, kebersihan tanaman gambir dari gulma lain juga perlu diperhatikan serta pemberian pupuk setelah selesai pemanenan daun gambir.

Harga merupakan suatu nilai tukar yang diperoleh petani berdasarkan harga jual barang yang dihasilkan oleh petani gambir. Harga juga sangat berpengaruh terhadap pendapatan petani gambir. Semakin tinggi harga komoditas yang dijual petani cenderung akan meningkatkan pendapatan. Terjadinya penurunan harga gambir otomatis akan mengakibatkan penurunan tingkat pendapatan petani gambir serta mengakibatkan perlambatan pada perekonomian masyarakat. Pengaruh harga gambir akan mendorong peningkatan jam kerja.

Pendapatan petani gambir di Kecamatan Sitellu Tali sangat beragam yaitu berkisar antara Rp 2.000.000 - Rp 5.000.000/ Bulan. secara umum pendapatan tersebut diperoleh dari hasil penjualan gambir yang diolah secara tradisional. Minimnya teknologi dan pengetahuan petani dalam memproduksi gambir mengakibatkan kualitas gambir tidak memiliki standart kualiitas yang sama, disi lain masih bergantungnya pada alam dalam memproduksi gambir menyebabkan biaya pengolahan masih dalam kategori mahal dan tidak efisien.

Faktor luas lahan, produksi, harga, dan jam kerja serta biaya produksi memegang peran penting untuk meningkatkan pendapatan petani gambir. Biaya produksi adalah biaya-biaya yang digunakan petani gambir untuk mengolah tanaman gambir menjadi barang setengah jadi untuk dijual guna memperoleh pendapatan. Setiap petani gambir mempunyai biaya produksi yang berbeda-beda, hal ini dipengaruhi oleh kemampuan serta modal yang tersedia oleh petani Gambir di Desa Bandar Baru Kecamatan Sitellu Tali Urang jehe Kabupaten Pakpak Bharat.

\section{TINJAUAN PUSTAKA}

a. Pendapatan

Menurut (Nazir, 2010) pendapatan merupakan suatu hasil yang diterima oleh seseorang atau rumah tangga dari proses berusaha atau bekerja. Menurut ilmu ekonomi pendapatan diartikan sebagai nilai maksimum yang dapat dikonsumsi oleh seseorang dalam 
satu periode seperti keadaan semula. Semakin tinggi pendapatan diperoleh maka tingkat konsumsi akan barang dan jasa cenderung meningkat pula. Defenisi tersebut menitikberatkan pada titik total kuantitatif pendapatan terhadap konsumsi selama satu periode.

Menurut (Soekartawi, 2002) pendapatan petani adalah selisih antara penerimaan (TR) dan semua biaya (TC). Untuk menghitung pendapatan bersih diperoleh dengan menggunakan rumus sebagai berikut :

$$
\begin{aligned}
& \pi=\mathrm{TR}-\mathrm{TC} \\
& \text { Dimana : } \\
& \pi \quad \text { : Pendapatan Bersih } \\
& \text { TR }: \text { Pendapatan Total } \\
& \text { TC }: \text { Biaya Total }
\end{aligned}
$$

Untuk menghitung pendapatan bersih terlebih dahulu harus diketahui tingkat pendapatan total dan pengeluaran pada periode tertentu. Pendapatan total diperoleh menggunakan persamaan yakni :

$\mathrm{TR}=\mathrm{P} \times \mathrm{Q}$

Dimana :

TR : Pendapatan Total

$\mathrm{P} \quad$ : Harga $(\mathrm{Rp} / \mathrm{kg})$

Q : Jumlah Produksi

Biaya diklasifikasikan menjadi dua yaitu biaya tetap (fixed cost) dan biaya tidak tetap (variabel cost). Biaya total tetap (TFC) adalah biaya yang relatif tetap jumlahnya dan terus dikeluarkan walaupun produksi yang diperoleh banyak atau sedikit. Biaya total variabel (TVC) adalah biaya yang besar kecilnya dipengaruhi oleh produksi yang diperoleh, contohnya biaya untuk tenaga kerja. Total biaya (TC) adalah jumlah dari total biaya tetap (TFC) dan biaya total variabel (TVC), secara matematikadapat ditulis sebagai berikut :

$\mathrm{TC}=\mathrm{TFC}+\mathrm{TVC}$

Dimana :

$$
\begin{aligned}
& \text { TC : Total Biaya } \\
& \text { TFC : Biaya Total Tetap } \\
& \text { TVC : Biaya Total Variabel }
\end{aligned}
$$

\section{b.Luas Lahan}

Menurut (Mubyarto, 2001) tanah merupakan faktor utama untuk kegiatan pertanian karena tanah merupakan tempat dimana usahatani dapat dilakukan dan tempat sebagai proses produksi. Tanah juga merupakan sebagai tempat bertumbuh dan berkembangnya tanaman dalam kegiatan pertanian. Tanah memiliki sifat tidak sama dengan faktor produksi lain yaitu luas relatif tetap dan permintaan akan lahan semakin meningkat seiring waktu sehingga sifatnya langka.

Luas penguasaan lahan pertanian merupakan suatu hal yang sangat penting dalam proses produksi atau usaha tani atau usaha pertanian. Dalam usaha tani misalnya kepemilikan dan penguasaan lahan sempit sudah pasti kurang efisien dibanding kepemilikan lahan yang luas. Kecuali bila usaha tani dijalankan dengan tertib dan administasi yang baik serta penggunaan teknologi yang tepat sehingga proses pengelolaan lahan pertanian dikelola secara maksimal. Tingkat efesiensi sebenarnya terletak pada penerapan teknologi. Karena pada luasan lahan yang sempit, penerapan teknologi cenderung kurang efesien atau berlebihan. Penggunaan teknologi sebaiknya diterapkan pada pengelolaan lahan pertanian dalam skala yang 
luas sehingga dapat menghemat tenaga kerja serta waktu pengelolaannya. Pemanfaatan teknologi berhubungan erat juga terhadap konversi luas lahan yang menjadikan usaha pertanian dapat dikelola dengan baik dibanding dengan pemanfaatan tekonologi pada lahan sempit yang cenderung kurang efisien (Daniel, 2004).

\section{c. Produksi}

Produksi adalah suatu proses pengubahan bentuk bahan baku menjadi produk bahan jadi dimana dalam pembuatan melibatkan tenaga kerja, bahan baku, mesin, energi, informasi, modal, dan tindakan manajemen. Proses produksi juga merupakan mengubah atau menambah nilai guna suatu barang dengan mengkombinasikan faktor-faktor produksi (Soeharno, 2009).

Menurut (Fuad, 2006) mendefinisikan produksi sebagai suatu kegiatan atau proses yang mentransformasikan masukan menjadi keluaran berupa barang dan jasa. Kegiatan produksi barang dan jasa bukan hanya pada sektor industri saja namun, kegiatan produksi juga terjadi pada sektor pertanian. Pada sektor pertanian kegiatan produksi ini beriorientasi pada proses menghasilkan bahan baku untuk produksi pada industri pengolahan.

Dalam usaha pertananian, produksi diperoleh melalui proses yang yang cukup panjang dan resiko. Panjangnya waktu yang dibutuhkan tidak tergantung pada jenis komoditas yang diusahakan, namun berkaitan dengan faktor-faktor produksi sebagai penentu pencapaian produksi. Masing-masing faktor produksi mempunyai fungsi yang berbeda dan saling terkait satu sama lain. jika salah satu faktor produksi tidak tersedia maka proses produksi tidak akan berjalan, terutama tiga faktor terdahulu seperti tanah, modal dan tenaga kerja. Tanpa tenaga kerja apa yang dapat dilakukan, begitu juga dengan faktor lain seperti modal.

Dalam proses produksi masing-masing komoditas membutuhkan faktor produksi sesuai dengan faktor genetiknya. Selain faktor produksi seperti (tanah, tenaga kerja, dan modal), terdapat faktor produksi pendukung lainnya untuk mendorong peningkatan produksi pertanian yakni manajemen/pengelolaan. Pada pertanian modern faktor produksi manajemen/pengolahan juga mempunyai peranan penting untuk mendorong proses produksi dibidang pengolahan dan pemasaran hasil pertanian, berbeda pada sistem pertanian tradisional sistem ini tidak menyebabkan proses produksi tidak berjalan atau batal sehingga produksi yang dihasilkan tidak memuaskan.

\section{d. Harga}

Menurut (Daniel, 2004) harga merupakan salah satu faktor yang sangat sulit dikendalikan. Berbagai upaya telah dilakukan oleh pemerintah mengenai harga, tetapi sampai saat ini tetap saja harga masih merupakan masalah, malah lebih berkembang lagi yang menjadi masalah besar bagi petani. Secara umum, harga adalah sesuatu yang sangat penting untuk dipertimbangkan oleh pembeli untuk memutuskan atau tidak membeli barang dan jasa yang dibutuhkan.

Menurut (Ekhaterina, 2008) harga merupakan nilai tukar suatu produk yang dinyatakan dalam satuan moneter atau uang. Harga suatu produk merupakan suatu faktor penentu permintaan pasar pada suatu barang atau 
produk. Harga berpengaruh terhadap posisi kompetisi perusahaan dan pangsa pasarnya yang disebabkan karena harganya. Untuk menjaga stabilitas harga sehingga tidak menguntungkan sepihak dan merugikan sepihak, peran serta pemerintah sangat diperlukan dalam hal ini.

\section{e. Jam Kerja}

Menurut (Kosasih, 2000) menyatakan bahwa pengaturan waktu termasuk dalam pengaturan tenaga kerja yang berkenaan dengan jadwal jam kerja dan jumlah tenaga kerja yang akan dipertahankan. Analisis jam kerja merupakan bagian dari teori ekonomi mikro, khususnya pada teori penawaran tenaga kerja yaitu tentang kesediaan individu dalam bekerja dengan harapan memperoleh penghasilan yang akan diperolehnya.

Jam kerja sering juga disebut jumlah atau lamanya waktu yang digunakan untuk melakukan pekerjaan baik dibidang produksi maupun dibidang jasa. Dalam sektor pertanian, subsektor perkebunan jam kerja juga mempengaruhi jumlah produksi uang dihasilkan. Kesediaan tenaga kerja untuk bekerja dengan jam kerja tertentu merupakan keputusan invidividu dalam bekerja (Wicaksono:2011).

\section{f. Biaya Produksi}

Menurut Mulyadi (2002) biaya adalah pengorbanan sumber ekonomi yang diukur dalam satuan uang, yang telah terjadi atau kemungkinan akan terjadi untuk mencapai tujuan tertentu. Biaya memegang peranan penting untuk kelancaran produksi barang dan jasa baik dalam preusahaan maupun produksi bahan baru pada sektor pertanian.
Menurut Supriyono (2000) biaya adalah harga perolehan yang dikorbankan atau digunakan dalam rangka memperoleh penghasilan atau revenue yang akan dipakai sebagai pengurangan penghasilan.

\section{METODE PENELITIAN}

Pendekatan yang digunakan dalam penelitian adalah metode deskriptif kuanitatif. Kajian penelitian ini mencakup pendapatan rumah tangga masyarakat petani Gambir di Desa Bandar Baru, Kecamatan Sitellu Tali Urang Jehe.

\section{Lokasi dan Waktu Penelitian}

Penelitian ini dilaksanakan di Desa Bandar Baru, Kecamatan Sitellu Tali Urang Jehe dengan konsep penelitian berdasarkan kerangka konseptual yang akan dilaksanakan seperti luas lahan, produksi, harga gambir, jam kerja, dan biaya produksi.

Penelitian dilakukan di Desa Bandar Baru sebagai lokasi penelitian dikarenakan pekerjaan sehari-hari masyarakat di desa tersebut berfokus pada pengolahan tanaman perkebunan gambir. Penelitian ini dilakukan selama 6 bulan dari bulan November 2020 sampai dengan April 2021.

\section{Jenis dan Sumber Data}

Penelitian ini menggunakan data primer dan sekunder. Data sekunder diperoleh dari yang instansi terkait, sedangkan data primer dihimpun dengan menyebarkan kuesioner kepada 79 Kepala Keluarga (responden) petani gambir di Desa Bandar Baru, Kecamatan Sitellu Tali Urang Jehe.

Metode Analisis Data 
Analisis yang digunakan pada penelitian ini menggunakan regresi linier berganda menggunakan aplikasi aplikasi statistical product and sevice solutions (SPSS) guna mengetahui pengaruh Luas Lahan, produksi, Harga, dan Jam kerja terhadap pendapatan petani gambir di Kecamatan Sitellu Tali Urang Jehe rumus:

$$
\begin{aligned}
& \mathrm{Y}=\alpha+\beta_{1} \mathrm{X}_{1}+\beta_{2} \mathrm{X}_{2}+\beta_{3} \mathrm{X}_{3}+\beta_{4} \mathrm{X}_{4}+\beta_{5} \mathrm{X}_{5}+e \\
& \text { Dimana: } \\
& \mathrm{Y} \quad=\text { Pendapatan Petani Gambir } \\
& \alpha \quad=\text { Konstanta } \\
& \beta_{1} \beta_{2} \beta_{3} \beta_{4} \beta_{5} \quad=\text { Koefisien Regresi } \\
& \mathrm{X}_{1} \quad=\text { Luas Lahan } \\
& \mathrm{X}_{2} \quad=\text { Produksi } \\
& \mathrm{X}_{3} \quad=\text { Harga } \\
& \mathrm{X}_{4} \quad=\text { Jam kerja } \\
& \mathrm{X}_{5} \quad=\text { Biaya produksi } \\
& e \quad \quad=\text { Variabel pengganggu }
\end{aligned}
$$

\section{HASIL DAN PEMBAHASAN}

\section{a. Analisis Deskriptif Variabel Pendapatan}

\section{Petani Gambir (Y)}

Distribusi frekuensi pendapatan petani gambir dari 79 kepala keluarga tercatat pendapatan petani gambir sebesar 2.100,0003.000,000 sebanyak 35 Kepala Keluarga dengan persentase $44,30 \%$, pendapatan petani gambir 3.100,000-4.000,000 sebanyak 32 Kepala Keluarga dengan persentase $40,51 \%$, pendapatan petani gambir 4.100,000-5.000,000 sebanyak 12 Kepala Keluarga dengan persentase 15,19\%.

\section{b. Analisis Deskriptif Variabel Luas Lahan} (X1)

Distribusi frekuensi luas lahan dari 79 kepala Keluarga tercatat luas lahan 100-1000 m² sebanyak 41 Kepala Keluarga dengan nilai persentase $51,90 \%$, luas lahan $1100-2000 \mathrm{~m}^{2}$ sebanyak 38 Kepala Keluarga dengan nilai persentase $48,10 \%$.

\section{c. Analisis Deskriptif Variabel Produksi (X2)}

Distribusi frekuensi produksi gambir dari 79 responden Kepala Keluarga tercatat produksi 10100 kilogram diperoleh data 53 Kepala Keluarga dengan persentase $63,09 \%$, dan produksi 110 200 kilogram diperoleh 26 Kepala Keluarga dengan persentase $32,91 \%$.

\section{d. Analisis Deskriptif Variabel Harga (X3)}

Distribusi frekuensi harga gambir dari 79 responden Kepala Keluarga tercatat tingkat harga gambir 41.000-50.000 sebanyak 40 penjualan Kepala Keluarga dengan persentase sebesar 50,63\%, harga gambir 31.000-40.000 dengan penjualan 39 Kepala Keluarga serta persentase sebesar $49,37 \%$.

\section{e. Analisis Deskriptif Variabel Jam Kerja} (X4)

Distribusi frekuensi variabel jam kerja petani dari 79 Kepala Keluarga sebagai responden diperoleh jam kerja 10-100 jam sebanyak 48 Kepala Keluarga dengan persentase sebesar 60,76\%, jam kerja 110-200 jam sebanyak 31 Kepala Keluarga dengan persentase sebesar $39,24 \%$.

\section{f. Analisis Deskriptif Variabel Biaya Produksi (X5)}

Distribusi frekuensi variabel biaya produksi petani gambir dari 79 Kepala keluarga tercatat biaya produksi 100,000-1.000,000 sebanyak 50 Kepala Keluarga dengan persentase 63,30\%, biaya produksi 1.100,000-2.000,000 sebanyak 29 Kepala Keluarga dengan persentase 36,70\%. 


\section{Analisis Inferensial}

Hasil analisis regresi linear berganda variabel luas lahan, produksi, harga, jam kerja, dan biaya produksi terhadap pendapatan petani gambir dari 79 Kepala Keluarga yang diambil sebagai responden dalam penelitian ini di Desa Bandar Baru Kecamatan Sitellu Tali Urang Jehe Kabupaten Pakpak Bharat.

Tabel 3. Hasil Regresi Linear Berganda

\begin{tabular}{|l|l|r|r|}
\hline \multirow{2}{*}{\multicolumn{2}{|c|}{}} & \multicolumn{2}{|c|}{$\begin{array}{c}\text { Unstandardized } \\
\text { Coefficients }\end{array}$} \\
\cline { 2 - 4 } \multicolumn{2}{|l|}{ Model } & \multicolumn{1}{|c|}{ B } & Std. Error \\
\hline 1 & (Constant) &, 565 &, 315 \\
& LUAS LAHAN (X1) &,- 041 &, 116 \\
& PRODUKSI (X2) &, 694 &, 111 \\
& HARGA (X3) &, 252 &, 083 \\
& JAM KERJA (X4) &, 472 &, 106 \\
& BIAYA PRODUKSI (X5) &, 524 &, 109 \\
\hline
\end{tabular}

Berdasarkan tabel 3. diperoleh hasil persamaan regresi linear berganda yaitu: $\mathrm{Y}=$ $0,565-0,041 X_{1}+0,694 X_{2}+0,252 X_{3}+0,472 X_{4}$ $+0,524 X_{5}$. Melalui persamaan tersebut maka dapat diintepretasikan sebagai berikut:

1. Nilai konstanta diperoleh 0,565 , maka pendapatan petani gambir meningkat sebesar 0,565/bulan. Dengan asumsi variabel lain konstan.

2. Hasil koefisien regresi luas lahan $-0,041$, maka akan terjadi penurunan pendapatan petani gambir sebesar 0,041/bulan. Dengan asumsi variabel lain tidak berubah (tetap).

3. Hasil koefisien variabel produksi sebesar 0,694, maka akan terjadi peningkatan pendapatan petani gambir sebesar Rp. 0,694/bulan. Dengan asumsi variabel lain tidak berubah (tetap).

4. Hasil koefisien variabel harga sebesar 0,252, maka akan terjadi peningkatan pendapatan petani gambir sebesar Rp. 0,252/bulan.
Dengan asumsi variabel lain tidak berubah (tetap).

5. Hasil koefisien variabel jam kerja sebesar 0,472, maka akan terjadi peningkatan pendapatan petani gambir Rp. 0,472/bulan. Dengan asumsi variabel lain tidak berubah (tetap).

6. Hasil koefisien variabel biaya produksi sebesar 0,524, maka akan terjadi peningkatan pendapatan petani gambir sebesar $\mathrm{Rp}$. 0,524/bulan dengan asumsi variabel lain tidak berubah (tetap).

\section{a. Uji-t (Parsial)}

Berdasarkan hasil pengujian, nilai $t$ signifikan variabel luas lahan yaitu t sig, 0,723 > 0,05 maka dapat dinyatakan bahwa luas lahan berpengaruh positif dan tidak signifikan terhadap pendapatan petani gambir di Desa Bandar Baru Kecamatan Sitellu Tali Urang Jehe Kabupaten Pakpak Bharat. Hasil penelitian ini bertolak belakang dengan hasil penelitian yang dilakukan oleh alitawan (2017) dengan judul penelitian "faktor-faktor yang mempengaruhi pendapatan petani jeruk pada Desa Gunung Bau Kecamatan Kintamani Kabupaten Bangli”. Bahwa secara parsial variabel Luas Lahan berpengaruh positif dan signifikan terhadap Pendapatan Petani Jeruk di Desa Gunung Bau Kecamatan Kintamani Kabupaten Bangli”.

Nilai t signifikan variabel produksi yaitu $\mathrm{t}$ sig, $0,000<, 05$ maka variabel produksi berpengaruh positif dan signifikan terhadap pendapatan petani gambir di Desa Bandar Baru Kecamatan Sitellu Tali Urang jehe Kabupaten Pakpak Bharat. Hasil penelitian ini didukung oleh hasil penelitian yang telah dilakukan oleh 
Safri Yanti (2014) dengan judul penelitian "Pengaruh Produksi Terhadap Pendapatan Petani Kelapa Sawit di Gampong Alue Peunawa Kecamatan Babahrot Kabupaten Aceh Barat Daya". Bahwa secara parsial variabel Produksi berpengaruh positif dan signifikan terhadap pendapatan Pendapatan Petani Kelapa Sawit di Gampong Alue Peunawa Kecamatan Babahrot Kabupaten Aceh Barat Daya.

Nilai $\mathrm{t}$ signifikan variabel harga yaitu $\mathrm{t}$ sig, $0,003<0,05$ maka variabel harga berpengaruh positif dan signifikan terhadap pendapatan petani gambir di Desa Bandar Baru Kecamatan Sitellu Tali Urang Jehe Kabupaten Pakpak Bharat. Hasil penelitian ini didukung oleh hasil penelitian yang dilakukan oleh Andi Arman Asriadi (2020) dengan judul penelitian "Pengaruh Harga dan Biaya Terhadap Pendapatan Petani Ubi Jalar Kecamatan Rumbia Kabupaten Jeneponto". Bahwa secara parsial variabel harga berpengaruh positif dan signifikan terhadap Pendapatan Petani Ubi Jalar Kecamatan Rumbia Kabupaten Jeneponto.

Nilai t signifikan jam kerja yaitu t sig, 0,000 $<$ 0,05 maka variabel jam kerja berpengaruh positif dan signifikan terhadap pendapatan petani gambir di Desa Bandar Baru Kecamatan Sitellu Tali Urang Jehe Kabupaten Pakpak Bharat. Hasil Penelitian ini didukung oleh hasil penelitian yang dilakukan oleh Aditya Dharma (2014) dengan judul penelitian "Pengaruh Faktor Sosial Demografi Terhadap Produktivitas Wanita Tukang Tenun Ikat di Kabupaten Klungkung”. Bahwa secara parsial variabel Jam kerja berpengaruh positif dan signifikan terhadap
Produktivitas Wanita Tukang Tenun Ikat di Kabupaten Klungkung.

Nilai t signifikan variabel biaya produksi yaitu $\mathrm{t}$ sig, $0,000<0,05$ maka biaya produksi berpengaruh positif dan signifikan terhadap pendapatan petani gambir di Desa Bandar Baru Kecamatan sitellu Tali Urang Jehe Kabupaten Pakpak Bharat. Hasil penelitian ini didukung oleh hasil penelitian yang telah dilakukan oleh Joni Arman Damanik (2014) dengan judul penelitian "Analisis Faktor-Faktor Yang Mempengaruhi Pendapatan Petani Padi di Kecamatan Masaran, Kabupaten Sragen”. Bahwa secara parsial biaya produksi berpengaruh positif dan signifikan terhadap Pendapatan Petani Padi di Kecamatan Masaran, Kabupaten Sragen. dan bertolak belakang dengan hasil penelitian Andesri Mulya (2018) dengan judul penelitian "Analisis faktor-faktor yang mempengaruhi pendapatan petani gambir di daerah Mahat Kabupaten 50". Bahwa secara parsial Biaya produksi berpengaruh negarif dan tidak signifikan terhadap pendapatan petani gambir di daerah Mahat Kabupaten 50.

\section{b. Uji-F (Simultan)}

Nilai uji $F$ sebesar 55,604 tingkat probabilitas sebesar $0,000<0,05$. Oleh karena nilai uji $\mathrm{F}$ sig, $0,000<0,05$ maka dapat dinyatakan bahwa luas lahan, produksi, harga, jam kerja, dan biaya produksi secara simultan berpengaruh positif dan signifikan terhadap pendapatan petani gambir di Desa Bandar Baru Kecamatan Sitellu Tali Urang Jehe Kabupaten Pakpak Bharat. 


\section{c. Uji Determinasi ( $R$ square $)$}

Hasil regresi koefisien determinasi diperoleh nilai $R$ square sebesar 0,792 atau $79,2 \%$. Maka variabel bebas (independen) seperti; luas lahan, produksi, harga, jam kerja, dan biaya produksi berpengaruh terhadap pendapatan petani gambir di Desa Bandar Baru Kecamatan Sitellu Tali Urang Jehe Kabupaten Pakpak Bharat sebesar 79,2\% sedangkan sisanya 20,8\% dipengaruhi oleh variabel lain yang tidak diteliti dalam penelitian ini.

\section{KESIMPULAN DAN SARAN}

Berdasarkan hasil penelitian yang telah dilakukan pada petani gambir di Desa Bandar Baru dan dari hasil pengujian secara simultan maka diperoleh hasil bahwa luas lahan, produksi, harga, jam kerja, dan biaya produksi secara simultan berpengaruh positif dan signifikan terhadap pendapatan petani gambir di Desa Bandar Baru Kecamatan Sitellu Tali Urang Jehe Kabupaten Pakpak Bharat. Sedangkan hasil pengujian secara parsial hanya variabel luas lahan yang berpengaruh dan tidak signifikan berpengaruh terhadap pendapatan petani gambir di Desa Bandar Baru.

\section{Saran}

Merujuk pada kesimpulan maka saran penelitian ini dalam peningkatan pendapatan petani gambir di Desa Bandar Baru Kecamatan Sitellu Tali Urang Jehe Kabupaten Pakpak Bharat adalah :

1. Pengelolaan lahan perkebunan tanaman gambir di Desa Bandar Baru Kecamatan Sitellu Tali Urang Jehe Kabupaten Pakpak
Bharat dilakukan lebih efektif dan efisien guna meningkatkan produksi gambir.

2. Petani gambir sebaiknya menjaga kualitas produk gambir guna menjaga stabilisasi harga sehingga mendorong peningkatan pendapatan petani gambir di Desa Bandar Baru Kecamatan Sitellu Tali Urang Jehe Kabupaten Pakpak Bharat.

3. Pemerintah sebagai pengambil kebijakan diharapkan memberikan terobosan-terobosan baru dalam pengelolaan perkebunan tanaman gambir di Desa Bandar Baru Kecamatan sitellu Tali Urang Jehe Kabupaten Pakpak Bharat.

\section{REFERENSI}

Aditya Dharma I Gusti Ngurah Oka dan Ardhana Putu. 2014. "Pengaruh Faktor Sosial Demografi Terhadap Produktivitas Wanita Tukang Tenun Ikat Di Kabupaten Klungkung. E-Jurnal EP Unud, Vol,3(8), 376-383.

Andesri Mulya. 2018،“Analisis Faktor-Faktor yang Mempengaruhi Pendapatan Petani Gambir di Daerah Mahat Kabupaten 50”. [Skripsi]. Universitas Negeri Padang

Anggriawan dan Toti Indrawati. 2013. "Peranan Komoditas Gambir Terhadap Perekonomian Kabupaten Lima Puluh Kota Provinsi Sumatera Barat”. Jurnal Ekonomi, Vol. 21 (2), 1-12.

Angipora, Marius.P. 2002. Dasar-Dasar Pemasaran. Jakarta : PT, Raja Garafindo Persada. 
Alitawan, Anak Agung Irfan. 2017. FaktorFaktor Yang Mempengaruhi Pendapatan Petani Jeruk Pada Desa Gunung Bau Kecamatan Kintamani Kabupaten Bangli E-Jurnal EP Unud, Vol, 6 (5),796-826.

Asriadi, Andi Arman. 2020. "Pengaruh Harga dan Biaya Terhadap Pendapatan Petani Ubi Jalar Kecamatan Rumbia Kabupaten Jeneponto”. Jurnal AGRIFO, Vol. 5,(1), 52-59.

Damanik, Joni Arman. 2014. "Analisis FaktorFaktor Yang Mempengaruhi Pendapatan Petani Padi di Kecamatan Masaran, Kabupaten Sragen". Economics Development Analysis Journal, Vol, 3 (1), 212-224.

Daniel, Moehar. 2004. Pengantar Ekonomi Pertanian. Jakarta : PT, Bumi Aksara.

Ekatherina. 2008. “Analisis Pengaruh Harga Jual Produk Terhadap Profitabilitas Perusahaan Pada PT. Mega ELTRA (Persero)". Medan: Universitas Sumatera Barat.

Fuad, M. 2006. Pengantar bisnis. Jakarta : PT, Gramedia Pustaka Utama.

Gilarso, T. 2004, Pengantar Ilmu Ekonomi Makro. Yogyakarta : Kansius.

Gujarati, Damodar. 2003. Dasar-dasar Ekonometrika. Jakarta : Erlangga.

Hanafie, R. 2010, Pengantar Ekonomi Pertanian. Yogyakarta : CV, ANDI OFFSET.

Kasmir. 2011. Manajemen Perbankan. Jakarta : PT, Raja Grafindo Persada.
Nasution, Amelira Haris. 2015. "Peran Kelembagaan Dalam Pengolahan dan Pemasaran Gambir di Kabupaten Lima Puluh Kota".[Tesis]. Institut Pertanian Bogor.

Mankiw, N. G. 2003. Pengantar Ekonomi. Jilid 2. Jakarta : Erlangga

Manurung, Mandala. 2010. Teori Ekonomi Mikro. Jakarta : Lembaga Universitas Indonesia.

Mubyarto. 2001. Pengantar Ekonomi Pertanian. Jakarta : LP3ES.

Nasrul, Wedy, Indra Masrin. 2015. "Faktorfaktor Penentuan Harga ( Studi Kasus: Pasar Gambir Nagari Lubuak Alai Kecamatan Kapur IX Lima Puluh Kota)".Fakultas Ekonomi. Vol.1 (1), 1-6. Nasution, Nora dan Edison Sagala. 2016. "Faktor-Faktor Yang Mempengaruhi Pendapatan Petani Salak di Desa Parsalakan Angkola Barat Tapanuli Selatan”. Jurnal Plans, Vol, 11 (11),1-11.

Oktavia. N. S, Darwanto. 2020. “Analisis FaktorFaktor Yang Mempengaruhi Produksi Komoditas Gambir”. Jurnal Pertnaian dan Agribisnis, 4 (3), 1-12.

Sardjono, Sigit. 2017, Ekonomi Mikro Teori dan Aplikasi. Yogyakarta : ANDI.

Sarno dan Bondan Hary Setiawan. 2013. "Analisis Karakteristik Sosial Ekonomi Yang Mempengaruhi Tingkat Pendapatan Pendapatan Petani Melato Gambir di Kecamatan Rakit Kabupaten Banjarnegara Jawa Tengah”. Politeknik Banjarnegara. 
Soeharno. 2009. Teori Ekonomi Mikro.

Yigyakarta : ANDI.

Soekartawi. 2002. Prinsip Ekonomi Pertanian. Jakarta : PT. Raja GR.

Sudarman, Ari. 2004. Teori Ekonomi Mikro.

Edisi Keempat. Yogyakarta : BPFEYoyakarta.

Sugiyono. 2017. Statistik Untuk Penelitian.

Bandung : Alfabeta.

Sukirno, Sadono. 2006, Makroekonomi Moden. Jakarta : PT. Raja Grafindo Persada.

Sumarsono, S. 2003. Ekonomi Manajemen

Sumber Daya Manusia dan

Ketenagakerjaan. Yogyakarta : Graha Ilmu.

Undang-Undang Nomor 25 Tahun 1997 Tentang Ketenagakerjaan.

Yanti, Safri. 2014. "Pengaruh Produksi Terhadap Pendapatan Petani Kelapa Sawit Di Gampong Alue Peunawa Kecamatan Babahrot Kabupaten Aceh Barat Daya".[Skripsi]. Universitas Teuku Umar 